\title{
Hanford Site Guide for Preparing and Maintaining Generator Group Pollution Prevention Program Documentation
}

Date Published

November 1998

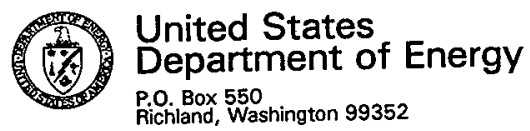

Approved for Public Release 


\section{RELEASE AUTHORIZATION}

Document Number: DOE/RL-95-103, Revision 3

Hanford Site Guide for Preparing and Maintaining

Document Title: Generator Group Pollution Prevention Program Documentation

This document, reviewed in accordance with DOE Order 241.1, "Scientific and Technical Information Management,"and 241.1-1, "Guide to the Management of Scientific and Technical Information," does not contain classified or sensitive unclassified information and is:

\section{APPROVED FOR PUBLIC RELEASE}

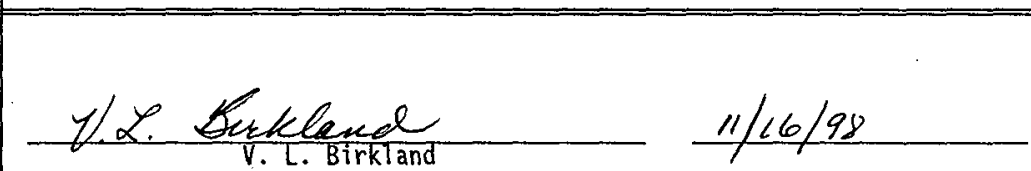

Lockheed Mart in Services, Inc.

Document Control/Information Clearance

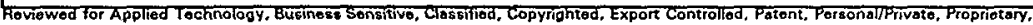
Protectod CRADA, Tradomark, Unciastified Controlled Nuclear Information.

Trademark Disclaimer. Reforonce herein to any specific commercial product, process, or service by trade name, trademark, manufacturer, or otherwise, does not necessarily constitute or imply its endorsement, recommendation, or favoring by the United States Government or any agency thereof or its contractors or subcontractors. The views and opinions of authors expressed herein do not necessarily state or reflect those of the United States Government or any agency thereof. This report has been reproduced from the best available copy.

Printed in the United States of Americe.

Available to the U.S. Department of Energy and its contractors from the U.S. Department of Energy Office of Scientific and Technical Information, P.O. Box 62, Oak Ridoe, TN 37831; Telephone: 423/676-8401.

Available to the public from the U.S. Department of Commerce National Technical Information Service, 5285 Part Royal Roes, Springfield, VA 22161: Telephone: 703/487-4650. 
TRADEMARK DISCLAMER

Reference herein to any specific commercial product, process, or service by trede name, trademark, manufacturer, or otherwise, does not necessarily constitute or imply its ondorsement, recommendation, or favoring by the United States Government or any agency thereof or its contractors or subcontractors.

This report has been reproduced from the best available copy. Available in paper copy and microfiche.

Available to the U.S. Department of Energy

and its contractors from

U.S. Department of Energy

Office of Scientific and Technical Information (OSTI)

P.O. Box 62

OBk Fidge, TN 37831

(615) 576-8401

Available to the public from the U.S. Department of Commerce Netional Technical Infomation Service (NTIS)

5285 Port Royal Rosd

Springfield, VA 22161

(703) $487 \cdot 4650$

Printed in the United Stetes of Amarice

DISCLM-5.CHP (8-95) 


\begin{abstract}
This document provides guidance to generator groups for preparing and maintaining documentation of Pollution Prevention/Waste Minimization (P2/WMin) Program activities. The guidance is one of a hierarchical series that includes the Hanford Site Waste Minimization and Pollution Prevention Awareness Program Plan (DOE-RL, 1998a) and Prime contractor implementation plans describing programs required by Resource Conservation and Recovery Act of 1976 (RCRA) 3002(b) and 3005(h) (RCRA and EPA, 1994). Documentation guidance for the following five $\mathrm{P} 2 / \mathrm{WMin}$ elements are discussed:

- Fiscal Year (FY) Goals

- Budget and Staffing

- Waste Minimization (WMin) Assessments (WMAs)

- Quarterly Pollution Prevention (P2) Reporting

- WMin Certification

Hanford Home Page access to P2 reporting and WMin certification forms is discussed, and hard copies of the following forms are provided in the appendices:
\end{abstract}

- Quarterly Report on Waste Reduction Accomplishments

- Quarterly Status Report

- WMin Certification Form 
DOE/RL-95-103, Rev. 3

This page intentionally left blank. 


\section{CONTENTS}

ABSTRACT
LIST OF TABLES
GLOSSARY
ABBREVIATIONS AND ACRONYMS
DEFINITIONS

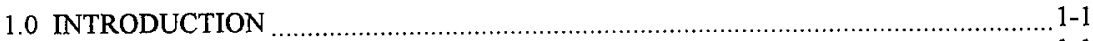

1.1 PURPOSE OF GUTDE

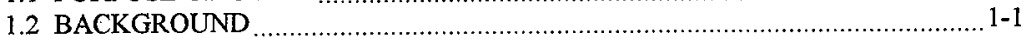

2.0 REQUIRED POLLUTION PREVENTION/WASTE MINIMIZATION

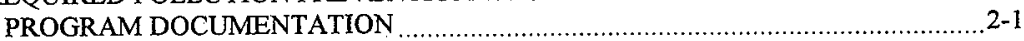

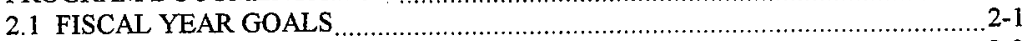

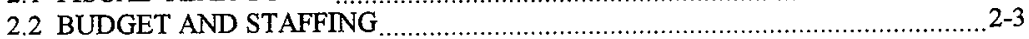

2.2.1 Pollution Prevention Budget Documentation Requirements ........................2-3

2.3 WASTE MINIMIZATION ASSESSMENTS …..............................................

2.4 POLLUTION PREVENTION/WASTE MINIMIZATION REPORTING .............. 2-4

2.4.1 Pollution Prevention Quarterly Reports ..................................................2-4

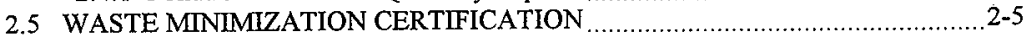

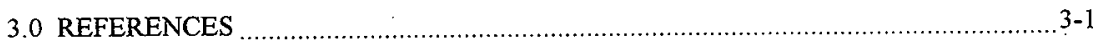

\section{APPENDICES}

A POLLUTION PREVENTION PROGRAM ELEMENTS ........................................... A-1

B SECRETARIAL MEMORANDUM: DEPARTMENT POLLUTION PREVENTION GOALS

C EPA-DESIGNATED AFFIRMATIVE PROCUREMENT PRODUCTS LIST ................ C-1

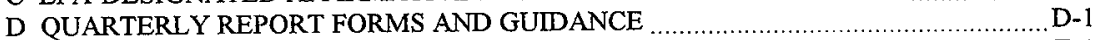

E WASTE MINIMIZATION CERTIFICATION FORM .............................................. E-1

\section{LIST OF TABLES}

1-1 Key Program Elements for Generator Group Pollution Prevention Program Documentation

2-1. Instructions for Preparing Fiscal Year Pollution Prevention/Waste Minimization Goals 


\section{GLOSSARY}

\section{ABBREVIATIONS AND ACRONYMS}

BHI

CFR

DOE

DOE-HQ

DOE-RL

EPA

EPCRA

FDH

FR

FTE

FY

HLW

LEFF

LLW

MLLW

MTRU

OHAZ

P2

P2OA

P2/WMin

PCB

PNNL

POC

RCRA

RHAZ

RL

SAN

SpG

SWITS

TRU

TSCA

USC

WAC

WMin

WMA

WMH
Bechtel Hanford, Inc

Code of Federal Regulations

U.S. Department of Energy

U.S. Department of Energy, Headquarters

U.S. Department of Energy, Richland Operations Office

U.S. Environmental Protection Agency

Emergency Planning and Community Right-To-Know Act of 1986

Fluor Daniel Hanford, Inc.

Federal Register

Full Time Equivalent

Fiscal Year

High-Level Waste

Process Waste Water

Low-Level Waste

Mixed Low-Level Waste

Mixed Transuranic Waste

State Regulated Waste

Pollution Prevention

Pollution Prevention Opportunity Assessment

Pollution Prevention/Waste Minimization

Polychlorinated biphenyl

Pacific Northwest National Laboratory

Point of Contact

Resource Conservation and Recovery Act of 1976

RCRA Hazardous Waste

U.S. Department of Energy, Richland Operations Office

Solid Sanitary Waste

Specific Gravity

Solid Waste Information Tracking System

Transuranic Waste

Toxic Substances Control Act of 1976

United States Code

Washington Administrative Code

Waste Minimization

Waste Minimization Assessment

Waste Management Federal Services of Hanford, Inc. 


\section{DEFINITIONS}

Affirmative Procurement. A Program that ensures that items composed of recovered materials will be purchased to the maximum extent practicable, consistent with Federal law and procurement regulations (RCRA, Section 6002 and 40 CFR 247). Guidance on this program has been issued and is updated as the U. S. Environmental Protection Agency issues additional guidelines.

Cleanup/Stabilization Waste. Cleanup/stabilization includes environmental restoration of contaminated media (soil, groundwater, surface water, sediments, etc.), stabilization of nuclear and non-nuclear (chemical) materials, and deactivation and decommissioning (including decontamination) of facilities.

Cleanup/stabilization waste consists of one-time operations waste produced from environmental restoration activities, including primary and secondary wastes associated with retrieval and remediation operations, "legacy wastes," and wastes from decontamination and decommissioning/transition operations. It also includes all Toxic Substances Control Act of 1976 regulated wastes, such as $\mathrm{PCB}$-contaminated fluids or equipment.

Cleanup/stabilization activities that generate wastes do not necessarily occur at a single point in time, but may last for several years while producing wastes. By definition, these activities are not considered to be routine (periodic and/or on-going), because the waste is a direct result of past operations and activities, rather than a current process. Newly generated wastes that are produced during these "one-time operations" are considered a secondary waste stream, and are separately accounted for whenever possible. This secondary (newly generated) waste usually results from common activities such as handling, sampling, treatment, repackaging, shipping, etc.

Generator. Each contractor within the scope of the P2/WMin Program whose activities or processes produce waste.

Generator Group. As defined by the responsible contractor, any discrete activity, project, or facility whose act or process produces waste.

Goal. A specific result toward which efforts are directed.

Hazardous Substance. Any hazardous substance listed as a hazardous substance in the Emergency Planning and Community Right-to-Know Act of 1986 and any further updates, and all ozone depleting compounds as defined by the Montreal Protocol of October 1987 and any further updates of the protocol.

Hazardous Waste. Those solid wastes that exhibit any of the characteristics of hazardous waste identified in 40 CFR 261, Subpart C (i.e., ignitable, corrosive, reactive, or toxic), or that are listed in 40 CFR 261, Subpart D, "List of Hazardous Waste."

Low-Level Waste. Waste that contains radioactivity and is not classified as high-level 
waste, transuranic waste, or spent nuclear fuel, or by-product material as defined by DOE Order 5820.2A (DOE, 1988). Test specimens of fissionable material that are irradiated for research and development only, and not for the production of power or plutonium, may be classified as Low-Level Waste, provided the concentration of transuranic is less than 100 nanocuries per gram $(\mathrm{nCi} / \mathrm{g})$.

Mixed Low-Level Waste. Low-Level Waste containing hazardous components as defined by the RCRA (also low-level mixed waste).

Mixed Waste. Waste containing both radioactive and hazardous components as defined by the Atomic Energy Act of 1954 and RCRA, respectively.

Non-Routine Waste. Identical to waste from cleanup/stabilization activities.

Pollutant. A substance whose dispersion into the environment has a deleterious effect on the ecosystem.

Pollution Prevention. The use of materials, processes, and practices that reduce or eliminate the generation and release of pollutants, contaminants, hazardous substances, and waste into land, water, and air. For the U. S. Department of Energy, this includes recycling activities.

Pollution Prevention Opportunity Assessment. Evaluation and appraisal of a process, activity, or operation as a way to identify potential WMin opportunities.

Process Waste Water. Any water produced during manufacturing or processing operations that comes into direct contact with or results from the production or use of any raw material, intermediate product, finished product, by-product, or waste product. This determination is independent of the level and/or nature of the contaminants. Additionally, process waste waters are liquid wastes, which are directly piped to a permitted (on-site) waste treatment facility where treatment may consist of neutralization, evaporation, or placement in a settling or percolation pond, etc. This term does not include the liquid discharges to publicly owned treatment works, which are governed by U.S. Environmental Protection Agency-or state-issued national pollutant discharge elimination system permits, or local pretreatment standards.

RCRA-Regulated Waste. Solid waste, not specifically excluded from regulations under 40 CFR 261.4, "Identification and Listing of Hazardous Waste," or delisted by petition, that is either a listed hazardous waste ( 40 CFR 261.30 to 261.33) or exhibits the characteristics of a hazardous waste (40 CFR 261.20 to 261.24).

Recycling. Recycling techniques are characterized as use, reuse, and reclamation techniques (resource recovery). Use or reuse involves the return of a potential waste material either to the originating process as a substitute for an input material or to another process as an input material. Reclamation is the processing or regeneration of a material to recover a useable product. 
Routine Operations Waste. Normal operations waste produced from any type of production, analytical, and/or research and development laboratory operations; treatment, storage, or disposal operations; "work-for-others;" or any periodic and recurring work that is considered ongoing. The term "normal operations" refers to the type of ongoing process (e.g., production) not the specific activity that produced the waste. Periodic laboratory or facility clean-outs and spill cleanups that occur as a result of these processes are also considered normal operations.

Sanitary Waste. All non-hazardous and non-radioactive waste disposed in a sanitary landfill including demolition waste, industrial wastes, and wastes such as garbage generated by normal housekeeping activities.

Segregation. The practice of separating or isolating contaminated materials from noncontaminated materials, or the separation/isolation of one waste type from another in an attempt to minimize the amount of the more noxious (and costly) material for disposal.

Source Reduction. The elimination or reduction of waste generation at the source. Source reduction activities and techniques include substitution of less hazardous materials, process optimization or modification, technology changes and administrative changes (inventory control), and housekeeping practices (material segregation). Source reduction results in reducing or eliminating potential waste material exiting from a process.

State-Only Dangerous Waste. Any other hazardous waste not specifically regulated under TSCA or RCRA, such as used oil, that may be regulated by Washington State Department of Ecology under WAC 173-303.

Transuranic Waste. Without regard to source or form, waste that is contaminated with alpha-emitting transuranium radionuclides with half-lives greater than 20 years and concentrations greater than $100 \mathrm{nCi} / \mathrm{g}$ at the time of assay. Heads of Field Elements can determine that other alpha contaminated wastes, peculiar to a specific site, must be managed as transuranic waste (DOE, 1988).

Treatment. Any method, technique, or process (including neutralization) designed to change the physical, chemical, or biological character or composition of any hazardous, radioactive, or sanitary waste so as to neutralize such waste, to recover energy or material resources from the waste, or to render such waste non-hazardous; safer to transport, store, or dispose; or amenable for recovery or storage; or reduced in volume.

TSCA-Regulated Waste. Wastes, both liquid and solid, containing more than 50 parts per million (ppm) of PCBs or PCBs regulated for disposal (DOE, 1996).

Waste Minimization. Elimination or minimization of the generation of waste before treatment, storage, or disposal. Waste minimization is any source reduction or recycling activity that results in (1) reduction of total volume of waste, (2) reduction of toxicity of waste, or (3) both, as long as that reduction is consistent with the general goal of minimizing present and future threats to human health and the environment. 
DOE/RL-95-103, Rev. 3

Waste Minimization Assessment. An evaluation and appraisal of a process, activity, or operation to identify potential waste minimization opportunities. Waste minimization assessments include pollution prevention opportunity assessments, value engineering studies, and engineering studies.

Waste Reduction. Reduction of the total amount of waste that is generated and disposed of by DOE operations through WMin and treatment activities. 


\subsection{INTRODUCTION}

\subsection{PURPOSE OF GUIDE}

This document provides guidance to contractor generator groups for developing and maintaining documentation of $\mathrm{P} 2 /$ WMin Program activities. The program documentation is intended to demonstrate generator compliance with U. S. Department of Energy (DOE) requirements as well as state and Federal regulations. The guidance is one of a hierarchical series that inciudes the Hanford Site Waste Minimization and Pollution Prevention Awareness Program Plan (DOE-RL, 1998a) and Prime contractor implementation plans describing programs required by RCRA 3002(b) and 3005(h) (RCRA and EPA, 1994).

\subsection{BACKGROUND}

The purpose of the Hanford Site P2/WMin Program is to eliminate or reduce waste generation and pollutant releases to the environment, use of toxic substances, and to conserve resources. The P2/WMin Program, has been developed to meet P2/WMin public law requirements, Federal and state regulations, and DOE requirements (DOE-RL, 1998a). The Hanford Site P2/WMin Program is implemented through sitewide and contractor programs. The Hanford Site Waste Minimization and Pollution Prevention Awareness Plan (DOE-RL, 1998a) provides overall requirements. Each prime contractor (Fluor Daniel Hanford, Inc. (FDH), Bechtel Hanford, Inc. (BHI), and Pacific Northwest National Laboratory (PNNL) has an implementation plan describing how the requirements will be met (FDH, 1998, BHI, 1997, PNNL, 1998). The documentation guide identifies the documentation required to be maintained on file that demonstrates compliance with the requirements.

The U. S. Environmental Protection Agency (EPA) provides guidance for a RCRAcompliant WMin program (EPA, 1993). The DOE also outlines the elements of a generatorspecific P2 program (DOE, 1996). The EPA and DOE program elements are presented in Appendix A and are applicable at the Hanford Site, contractor, and generator group level.

Generator groups are required to maintain documentation on file only for the key P2 elements listed in Table 1-1. Documentation of these key elements will demonstrate compliance with regulatory, Federal, and Hanford Site requirements. 
DOE/RL-95-103, Rev. 3

Table 1-1

Key Program Elements for Generator Group Pollution Prevention Program Documentation.

FY Goals

Budget and Staffing - Budget and Full Time Equivalent (FTE) staff supporting P2/WMin activities.

WMAs

P2 Reporting - Quarterly reports

WMin Certification 
DOE/RL-95-103, Rev. 3

\subsection{REQUIRED POLLUTION PREVENTION/WASTE MINIMIZATION PROGRAM DOCUMENTATION}

This section discusses documentation for the P2/WMin elements that is to be kept on file.

\subsection{FISCAL YEAR GOALS}

Establishing goals is essential to a successful P2/WMin Program and is an important and required element of the Hanford Site P2/WMin Program. P2 goals are necessary to (1) meet Federal, state, and DOE regulations and reporting requirements; (2) provide a system for tracking progress and measuring success of P2/WMin activities; and (3) focus efforts on results-oriented, achievable activities that reduce the generation of waste and pollutants to all media, reduce the use of hazardous substances, and increase the conservation of energy and natural resources.

Generators or generator groups will establish FY waste reduction goals. FY waste reduction goals are to be submitted by October 15 th. FY goals are to be approved and signed by generator or generator group management and submitted to the Waste Management Federal Services of Hanford, Inc. (WMH) P2/WMin group and also filed with the generator's or generator group's program documentation. A suggested format for the documentation of established goals is provided in Table $2-1$.

In establishing waste reduction goals for wastes generated from routine operations, generators or generator groups should consider waste generation ceilings assigned to their company to support meeting the FY or Secretary of Energy's goals. Qualitative goals may be established. Generators and generator groups shall report progress toward attaining goals in their quarterly status reports.

The DOE has established waste reduction goals for waste generated from routine operations for the DOE complex to be achieved by December 31, 1999. The May 1996 memorandum from The Secretary of Energy announcing the goals is presented in Appendix B. Calendar Year 1993 waste generation data is the baseline year for these waste reduction goals. U.S. Department of Energy-Richland Operations Office (RL) has accepted these goals for the Hanford Site. These goals are applicable to the routine and cleanup/stabilization waste generators as noted. The goals are itemized below.

\section{- For Routine Operations:}

- Reduce the generation of Low-Level Waste (LLW) 50-percent

- Reduce the generation of Mixed Low-Level Waste (MLLW) 50-percent

- Reduce the generation of hazardous waste, including RCRA- and State-regulated wastes, 50-percent 


\section{Table 2-1. Instructions for Preparing Fiscal Year} Pollution Prevention/Waste Minimization Goals

1. List on the table below the waste generation forecast or other basis for the waste type listed.

2. Enter the estimated quantity resulting from source reduction and recycling as a percentage of the forecasted quantity.

Fiscal Year Goals For FY

Routine Waste Cleanup/Stabilization or Non-Routine Waste

\begin{tabular}{|l|c|c|c|c|}
\hline \multicolumn{1}{|c|}{ Waste classification } & $\begin{array}{c}\text { Waste forecast or } \\
\text { Other Basis of } \\
\text { Estimate }\end{array}$ & $\begin{array}{c}\text { Source } \\
\text { reduction } \\
\text { (Percent) }\end{array}$ & $\begin{array}{c}\text { Recycling } \\
\text { (Percent) }\end{array}$ & $\begin{array}{c}\text { Treatment } \\
\text { (Percent) }\end{array}$ \\
\hline Low-level waste (LLW) & $\left(\mathrm{m}^{3}\right)$ & & & \\
\hline Transuranic waste (TRU) & $\left(\mathrm{m}^{3}\right)$ & & & \\
\hline Mixed Low-level waste (MLLW) & $\left(\mathrm{m}^{3}\right)$ & & & \\
\hline Mixed Transuranic waste (MTRU) & $\left(\mathrm{m}^{3}\right)$ & & & \\
\hline RCRA Hazardous waste & $(\mathrm{mt})$ & & & \\
\hline State-only Dangerous waste & $(\mathrm{mt})$ & & & \\
\hline $\begin{array}{l}\text { Toxic Substances Control Act of } \\
\text { 1976 (TSCA)-regulated waste }\end{array}$ & $(\mathrm{mt})$ & & & \\
\hline
\end{tabular}

Approved:

Generator or Generator Group Management 
DOE/RL-95-103, Rev. 3

- Reduce the generation of sanitary waste 33-percent

- Reduce total releases and off-site transfers for treatment and disposal of Emergency Planning and Community Right-to-Know Act (EPCRA) 313 toxic chemicals 50-percent.

- For Routine Operations and Cleanup/Stabilization Activities:

- Recycle 33-percent of sanitary waste.

- Affirmative Procurement:

- Increase affirmative procurement of EPA-designated, recycled products listed in the Table C1-1 in Appendix C to 100-percent, except where they are not commercially available at a reasonable price or do not meet performance standards. The list of EPAdesignated products may also be found on the Affirmative Procurement page at http:// apsql05.rl.gov/polprev/ap/ap.htm. The list of EPA-designated products increases periodically. When procuring products, generators should check the above Uniform Resource Locator for the most current list of EPA-designated products.

Additional discussion on goals can be found in Hanford Site Waste Minimization and Pollution Prevention Awareness Program Plan (DOE-RL, 1998a) and prime contractor implementation plans.

\subsection{BUDGET AND STAFFING}

\subsubsection{Pollution Prevention Budget Documentation Requirements}

Hanford Site contractors are required to develop budgets for activities that will help contractor generator groups achieve their goals and the 18 objectives prescribed in the Pollution Prevention Program Plan (DOE, 1996) and the Hanford Site Waste Minimization and Pollution Prevention Awareness Program Plan (DOE-RL, 1998a). The DOE P2 program elements listed in Appendix A are to be considered in a P2 program for an individual facility. Separate, identifiable funding shall be established within individual cost account plans depending on contractor funding needs.

Copies of the appropriate budget documentation will be maintained as program documentation. In cases where funding is not established in separate budget documents, estimated budget information should be maintained as documentation. The quarterly status report, discussed in Section 2.4.1, also provides documentation of planned and actual budget as well as the P2 staffing level in FTEs. 


\subsection{WASTE MINIMIZATION ASSESSMENTS}

An important part of an effective P2/WMin Program is the identification of waste streams as well as the activities that produce those wastes. Once those waste streams have been characterized (constituents, concentrations, quantities), they can be prioritized and evaluated for reduction. In evaluating a given waste stream for reduction it is desirable that alternative reduction methods be considered and economically evaluated. Evaluating alternative waste reduction methods in order to identify waste reduction opportunities should be the primary purpose of a WMA. The preferred assessment method at the Hanford Site is conducting a Pollution Prevention Opportunity Assessment (P2OA). Other evaluation methods, such as value engineering studies, engineering evaluations, and P2/WMin in design assessments, are also acceptable.

The P2OA is a structured assessment process that utilizes a systematic approach to identify and document WMin opportunities. Training on conducting P2OAs is available from the WMH P2/WMin Group. The Pollution Prevention Opportunity Assessments - $A$ Training and Resource Guide, (DOE-RL, 1998b) is also available to help waste generator groups complete these activities.

WMAs must also be documented. Documentation should be maintained in the program documentation file. The results of WMAs should also be placed on the Hanford P2 Home Page at http://apsql05.rl.gov/polprev/default.asp. To place a WMA on the Hanford P2 Home Page, submit completed WMA along with an assessment summary in electronic format to their WMH $\mathrm{P} 2 /$ WMin point of contact (POC).

\subsection{POLLUTION PREVENTION/WASTE MINIMIZATION REPORTING}

This section discusses the P2/WMin reporting requirements. Reports should be submitted electronically using formats available at http://apsql05.rl.gov/polprev/areport/report.htm. Alternatively, if access to the Hanford intranet is unavailable, data may be submitted on hard copy to the WMH P2/WMin POC using the forms provided in Appendix D.

\subsubsection{Pollution Prevention Quarterly Reports}

A Quarterly Report shall be submitted by all Hanford Site waste generator groups on January 15th, April 15th, July 15th, and October 15th. The Quarterly Report is divided into two electronic forms: 1) Waste Reduction Accomplishments and 2) Status. Both forms are accessible via the Hanford P2 Home Page at http://apsq105.rl.gov/polprev/areport/report.htm. The WMH P2/WMin group is available to answer questions or provide further clarification on completing the Quarterly Reports. 
DOE/RL-95-103, Rev. 3

\subsection{WASTE MINIMIZATION CERTIFICATION}

All generator groups shall certify annualily that a WMin program is in place as required by RCRA 3002(b) and 3005(h) (RCRA), the Hanford Site Dangerous Waste Permit (EPA, 1994) and 40 Code of Federal Regulations (CFR) 264.73. A WMin certification form is shown in Appendix $\mathrm{E}$ and is also available on the Hanford P2 Home Page at http://apsq105.rl.gov/ polprev/areport/cert.htm. The form should be completed and signed by facility management and maintained on file in the facility's operating record. 
DOE/RL-95-103, Rev. 3

This page intentionally left blank.

$2-6$ 


\subsection{REFERENCES}

40 CFR 247, "Comprehensive Procurement Guideline for Products Containing Recovered Materials," Code of Federal Regulations, as amended.

40 CFR 261, "Identification and Listing of Hazardous Waste," Code of Federal Regulations, as amended.

40 CFR 264.73, "Operating Record," Code of Federal Regulations, as amended.

Atomic Energy Act of 1954, 42 USC 2011, et seq.

BHI, 1997, Environmental Contractor Waste Minimization and Pollution Prevention Program Plan, BHI-00099, Revision 2, Bechtel Hanford, Inc., Richland, Washington, October 1, 1997

DOE, 1988, Radioactive Waste Management, DOE Order 5820.2A, U.S. Department of Energy, Washington, D.C.

DOE, 1996, Pollution Prevention Program Plan, U.S. Department of Energy, DOE/S-0118, Washington, D.C.

DOE-RL, 1998a, Hanford Site Waste Minimization and Pollution Prevention Awareness Program Plan, DOE/RL-91-31, U. S. Department of Energy, Richland Operations Office, Richland, Washington, September 1998.

DOE-RL, 1998b, Pollution Prevention Opportunity Assessments-A Training and Resource Guide, DOE/RL-96-80, Revision 1, U.S. Department of Energy, Richland Operations Office, Richland, Washington, November 1998.

EPA, 1993, "Guidance to Hazardous Waste Generators on the Elements of a Waste Minimization Program," Federal Register, Vol. 58, No. 102, Washington, D.C.

EPA, 1994, Hanford Facility Dangerous Waste Permit, Permit Number WA7890008967, Hazardous and Solid Waste Amendments Portion, U. S. Environmental Protection Agency, Seattle, Washington.

EPCRA, Emergency Planning and Community Right-to-Know Act, as amended, 42 USC 11013, 11028 , et seq.

FDH, 1998, Project Hanford Management Contract Pollution Prevention Program Implementation Plan, HNF-EP-0496, Revision 3, Fluor Daniel Hanford, Inc., Richland, Washington, September 1998. 
DOE/RL-95-103, Rev. 3

PNNL, 1998, Pollution Prevention Program Implementation Plan, PNNL-MA-822, Revision 2 , Pacific Northwest National Laboratory, Richland, Washington, September 1998.

RCRA, Resource Conservation and Recovery Act of 1976, 42 USC 6901, et seq.

TSCA, Toxic Substances Control Act of 1976, 15 USC 2601, et seq.

WAC 173-303, Dangerous Waste Regulations, Publication No. 92-91, Amended November 1995, Washington State Department of Ecology, Olympia, Washington. 
DOE/RL-95-103, Rev. 3

APPENDIX A

POLLUTION PREVENTION PROGRAM ELEMENTS 
DOE/RL-95-103, Rev. 2

This page intentionally left blank. 
DOE/RL-95-103, Rev. 2

\section{POLLUTION PREVENTION PROGRAM ELEMENTS}

\section{A1.1 Generator Group Program Implementation Elements}

P2 program implementation elements recommended by the DOE are given below (DOE, 1996). Table A1-1 lists P2 program elements recommended by EPA (EPA, 1993). A descriptive reference that discusses each element is also indicated in Table A1-1.

1. Organization and Infrastructure

- Designate a generator group P2 coordinator

- Interface with the sitewide P2 coordinator(s)

- Participate in the sitewide P2 Network

- Institute corrective actions resulting from program evaluation.

2. Program Development

- Develop and maintain generator group P2 program documentation

- Establish goals

- Develop activity schedules for specific tasks and projects

- Obtain budgets for generator group programmatic activities

- Assign personnel to develop and implement the generator group P2 program

- Integrate P2 practices into operating procedures.

3. Sitewide Program Participation

- Involve employees in job-specific P2 practices

- Exchange information and technologies with other waste generator groups

- Seek technical assistance

- Track material use

- Report on material usage, recycling, and progress made in implementing P2 practices 
- Participate in sitewide waste reduction and recycling programs.

4. Training

- Identify job-specific P2 training needs

- Participate in P2OA and high Return on Investment training.

5. P2 Opportunity Assessments/Implementation

- Identify and evaluate current and potential waste-generating activities

- Identify and prioritize P2 opportunities

- Conduct P2OAs on waste streams

- Implement process modifications and material substitutions

- Evaluate the potential of new technologies on waste-generating activities.

6. Use affirmative procurement practices

- Encourage affirmative procurement in the purchase of EPA-designated recycle products.

\section{Design Considerations}

- Design P2 principles and practices into new and modified facilities

- Incorporate P2 into facility upgrades and process modifications and document these upgrades for projects in the conceptual design review/report phase of a project valued at a general plant project or higher.

8. Program Evaluation

- Evaluate generator group program implementation status

- Evaluate waste reduction/performance. 


\section{Table A1-1. U.S. ENVIRONMENTAL PROTECTION AGENCY WASTE MINIMIZATION PROGRAM ELEMENTS GUDANCE COMPLIANCE MATRIX}

\begin{tabular}{|c|c|c|}
\hline & $\begin{array}{c}\text { EPA guidance } \\
\text { WMin Program elements } \\
(\text { per RCRA })^{2}\end{array}$ & Program Element Descriptive Reference \\
\hline \multirow[t]{9}{*}{ A. } & Top management support & \\
\hline & Hanford Site policy & Hanford Site plan \\
\hline & Company policy & Contractor plan \\
\hline & Set goals & Hanford Site plan and contractor plan \\
\hline & $\begin{array}{l}\text { Commitment opportunity } \\
\text { implementation }\end{array}$ & Hanford Site plan and contractor plan \\
\hline & Facility coordinator & Contractor plan \\
\hline & Publicize successes & Hanford Site plan and contractor plan \\
\hline & Incentives & Hanford Site plan and contractor plan \\
\hline & Training & Hanford Site plan and contractor plan \\
\hline B. & $\begin{array}{l}\text { Characterization of waste } \\
\text { generation and waste } \\
\text { management costs }\end{array}$ & Hanford Site plan and contractor plan \\
\hline \multirow[t]{3}{*}{ C. } & WMAs & \\
\hline & Identification of opportunities & Hanford Site plan and contractor plan \\
\hline & $\begin{array}{l}\text { Determine true costs of the } \\
\text { waste }\end{array}$ & Contractor plan \\
\hline D. & Cost allocation system & Hanford Site plan and contractor plan \\
\hline E. & Technology transfer & Hanford Site plan and contractor plan \\
\hline F. & $\begin{array}{l}\text { Program implementation and } \\
\text { evaluation }\end{array}$ & Hanford Site plan and contractor plan \\
\hline
\end{tabular}


DOE/RL-95-103, Rev. 2

This page intentionally left blank. 
DOE/RL-95-103, Rev. 3

\author{
APPENDIX B \\ SECRETARIAL MEMORANDUM: \\ DEPARTMENT POLLUTION PREVENTION GOALS
}


DOE/RL-95-103, Rev. 3

This page intentionally left blank. 
DOE/RL-95-103, Rev. 3

The Segretary of Energy

Wassinglon, DC 20585.

May 3, 1996

MEMORANDUM FOR HEADS OF DEPARTMENTAL ELEYGBNTS

FROM:

HAZEL, R. O'LEARY

Departmental Pollution Prevention Goals

SUBJECT:

The Department of Energy pollution prevention strategy is to reduce the generation of all waste streans and thus minimize the inmpact of departmental opcrations on the environment. Preventing pollution also reduces risks to the health and safety of workers and the general public and saves searec budget doilars. To demorstrate the Department's comnitment to poilution prevention, we have set the following goals to be achieved by December 31, 1999, using calendar year 1993 as a baseline year.

For Routine Operations:

- Reduce by 50 percent the generation of radiosctive waste.

- Reduce by 50 percent the genteration of low-level mixed waste.

- Reduoe by 50 percent the generation of hazardous waste.

- Reducc by 33 percent the generation of sanitary waste.

- Redice by 50 percont total releases and off-site transfers for treatment and disposal of toxic shemicals.

For All Operations, Including Cleanup/Stabilization Actisities:

- Recycle 33 percent of sanitary waste.

For Aflirmative Procucement:

- Increase procurement of Environmental Protection Agency-designated, recycled products to 100 percent, cxcept where they are not commercially available competitively at a reasonable price or do not meet performanos standards.

Operations Offices will direct sites under their purview to set site-specifie goals to assist in achieving the departmertal goals. Progress toward mceting the departmental goals will be reported ansually to me. It is the resporsibitity of each Federal ind contractor manager to work diligently to meet these goals; to aggressively seek ways to reduce the amount of pollutants generased within the workplace; and to constrye, reuse, and recycle rcsourices. 
DOE/RL-95-103, Rev. 3

This page intentionally left blank. 
DOE/RL-95-103, Rev. 3

\section{APPENDIX C}

EPA-DESIGNATED AFFIRMATIVE PROCUREMENT PRODUCTS LIST 
DOE/RL-95-103, Rev. 3

This page intentionally left blank. 


\section{APPENDLX C}

\section{EPA-DESIGNATED AFFIRMATTVE PROCUREMENT PRODUCTS LIST}

Table $\mathrm{Cl}-1$ is a list of EPA-designated items considered for affirmative procurement.

Table C1-1. EPA-DESIGNATED AFFIRMATIVE PROCUREMENT PRODUCTS LIST

\begin{tabular}{|c|c|}
\hline Category & Designated Items \\
\hline Landscape Products & $\begin{array}{l}\text { - Hydraulic mulch } \\
\text { - Yard trimmings compost } \\
\text { - Garden and soaker hoses } \\
\text { - Lawn and garden edging } \\
\end{array}$ \\
\hline Park and Recreation Products & $\begin{array}{l}\text { - Playground surfaces } \\
\text { - Running tracks } \\
\text { - Plastic fencing } \\
\end{array}$ \\
\hline Construction Materials & $\begin{array}{l}\text { - Cement and concrete containing fly ash } \\
\text { - Cement and concrete containing blast furnace slag } \\
\text { - } \text { Cuilding insulation } \\
\text { - } \text { Carpet } \\
\text { - Laminated paperboard } \\
\text { - Patio block } \\
\text { - Structural fiberboard } \\
\text { - Consolidated and reprocessed latex paint } \\
\text { Shower and restroom dividers and partitions } \\
\end{array}$ \\
\hline Transportation Products & $\begin{array}{l}\text { - Traffic barriers } \\
\text { - Traffic cones } \\
\text { - Channelizers } \\
\text { - Delineators } \\
\text { - } \text { Flexible delineators } \\
\text { - Parking stops } \\
\end{array}$ \\
\hline Vehicular Products & $\begin{array}{l}\text { - Retread tires } \\
\text { - Re-refined lubricating oils } \\
\text { - Reclaimed engine coolants } \\
\end{array}$ \\
\hline Non-Paper Office Products & $\begin{array}{l}\text { - } \text { Binders } \\
\text { - Office recycling containers } \\
\text { - } \text { Office waste receptacles } \\
\text { - Plastic desktop accessories } \\
\text { - } \text { Tontic trash bags } \\
\text { - Plastridges } \\
\text { - Printer ribbons } \\
\end{array}$ \\
\hline
\end{tabular}


Table C1-1 (Continued). EPA-DESIGNATED AFFIRMATIVE PROCUREMENT PRODUCTS LIST

\begin{tabular}{|l|l|}
\hline \multicolumn{1}{|c|}{ Category } & \multicolumn{1}{c|}{ Designated Items } \\
\hline Paper Products & - Tissue products \\
& - Newsprint \\
& - Uncoated printing and writing papers \\
& $\begin{array}{l}\text { - Coated printing and writing papers } \\
\text { - Pristols }\end{array}$ \\
& - Tray liners \\
\hline Miscellaneous Products & - Pallets \\
\hline
\end{tabular}

References: Comprehensive Guideline for Procurement of Products Containing Recovered Materials (60 FR 21370, May 1, 1995), Recovered Materials Advisory Notice (60 FR 21386, May 1, 1995), and Paper Products Recovered Materials Advisory Notice (60 FR 26986, May 29, 1996) 
DOE/RL-95-103, Rev. 3

APPENDIX D

QUARTERLY REPORT FORMS AND GUTDANCE 
DOE/RL-95-103, Rev. 3

This page intentionally left blank.

D-2 


\section{D1.1 QUARTERLY REPORT FORMS AND GUIDANCE}

P2 quarterly report forms are included in this appendix. Guidance on report input is included in Sections D1.1.1 and D1.1.2 below. Forms are available for completion and submittal on the Hanford P2 Home Page at http://apsq105.ri.gov/polprev/default.asp.

Copies of these reports should be maintained on file in the generator group program documentation. 


\section{Add an Entry to the Database}

Facility:

Fiscal Year: $\square$
Quarter: $O$ 1st $\bigcirc$ 2nd $\bigcirc$ 3rd $\bigcirc$ 4th

Click on the icon for help.

Facility Name: 200 ETF/242-A Evaporator

Technical Contact: $\square$ Phone:

Waste Stream Name:

Waste Type: (LLW) Low-Level Waste

Waste Form: $\bigcirc$ Liquid $\circ$ Gas $\bigcirc$ Solid $\bigcirc$ Sludge

Waste Source: ${ }^{\circ}$ Routine ${ }^{\circ}$ Non-Routine

Describe the Waste Reduction Activity:

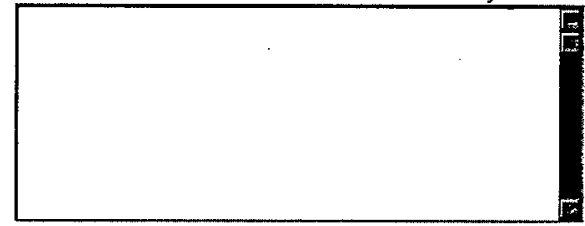

Was this activity the result of $\mathrm{P} 2$ in Design Opportunities? ${ }^{\circ}$ Yes ${ }^{\circ}$ No Waste Min Approach: ${ }^{\circ}$ Source Reduction $\bigcirc$ Recycling $\bigcirc$ Treatment O Segregation

5 Implementation Date:

Amount Reduced:

Amount Recycled: on-site

Units:

Density:

Density Units: off-site

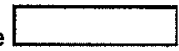


DOE/RL-95-103, Rev. 3

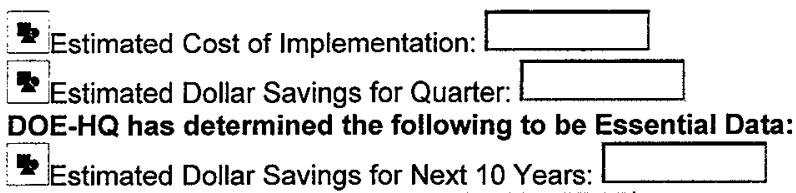

in

Return to: Hanford Home Page or Pollution Prevention Home Page

For specific questions or comments see our Contacts List or send feedback to David Nichols

URL: http://apsq/05.rl.gov/polprev/areport/quarter/Addform.asp 
DOE/RL-95-103, Rev. 3

\section{D1.1.1 Guidance for Quarterly Waste Reduction Accomplishments Report} below.

Help items for the Quarterly Report on Waste Reduction Accomplishments are provided

\section{Fiscal Year:}

Enter applicable FY.

Quarter:

Select applicable reporting quarter.

Facility Name:

Select the name of the Facility where the reduction/recycling/treatment occurred. If the facility does not appear in the list then leave blank. The facility name can be added by including it in the "Describe the Waste Reduction Activity" field below.

Technical Contact: Phone:

Provide the name and phone number of someone familiar enough with the details of this activity to answer questions on the technical content.

Waste Stream Name:

Please provide the Solid Waste Information Tracking System (SWITS) stream code, such as B003 or H016, if applicable. Otherwise, enter the descriptive stream name used at the facility to track cumulative quantities generated by this waste stream. If in doubt, check with the group . responsible for tracking/reporting quantities generated. The combination of Contractor, Facility Name, and Waste Stream Name must be unique in order to properly track waste reductions and report a rollup at the end of the year.

\section{Waste, Emission or Effluent Type:}

Click on the down-arrow at the end of the entry box and highlight the appropriate waste type. If the waste type you are reporting is not in the list then please contact your facility representative in the WMH P2/WMin Group.

The 10 choices are:

(LLW) Low-Level Waste

(MLLW) Mixed Low-Level Waste

(TRU) Transuranic Waste

(MTRU) Mixed Transuranic Waste 
(HLW) High-Level Waste

(RHAZ) RCRA Hazardous Waste

(OHAZ) State Regulated Waste

(SAN) Solid Sanitary Waste

(LEFF) Process Waste Water

(TSCA) TSCA-regulated waste (Polychiorinated Biphenyls (PCBs), etc.)

Waste Form:

Select one of the 4 waste forms by clicking the radio button preceding the form type you wish to select. The 4 choices are:

Liquid-mostly or all liquid. May contain some solids.

Gas-containerized

Solid-contains no free liquid

Sludge-mostly solids but contains some free liquid

Describe the Waste Reduction Activity:

Include the reason for initiating the activity, what was reduced and the actions that enabled the reduction of waste. This description is all the information that is available to those outside the Hanford area so please be as descriptive as possible.

This description needs to be entered only once into the database. If you have already reported this activity and provided a description then this field may be left blank.

Planned Opportunities Identified through P2 in Design:

If you have identified opportunities through $\mathrm{P} 2$ in design, provide a description and a projected implementation date.

Update these item in future quarterly reports only if the status changes.

WMin Approach:

Select one of the four options provided by clicking on the radio button immediately proceeding the correct approach.

Source Reduction

Recycling

Treatment

Segregation

DOE-HQ doesn't have an official definition for "segregation," but considers the following activities as segregation: 
Waste stream segregation/sorting

Survey for release/green-is-clean

Decontamination for salvage/reuse/recycle

Contamination control/containment

Loss prevention/spill control

Co-mingling prevention

Source reduction is any activity, which prevents the generation of the waste and includes such activities as procedure modification and product substitution.

Treatment is any activity that changes the physical nature of the waste.

Reuse-Recycling includes the use or reuse of a material.

If the waste was minimized using more than one approach then you must submit a form for each approach. Do not double report waste reduction quantities. Allocate the appropriate percentage to each approach such that the percentages total to $100 \%$.

\section{Implementation Date:}

Enter the date this activity was first implemented. Use the format $\mathrm{mm} / \mathrm{yy}$ for input. For example July 4, 1999 would be $07 / 99$.

This field is only for new activities implemented during the current reporting period. If the activity was implemented prior to this reporting period then leave blank or enter N/A.

\section{Amount Reduced:}

If you are reporting recycling information then leave this field blank. Otherwise - Enter the numeric value for the total Source Reduction (including hazardous constituent reduction) achieved during this reporting period. The units (kilogram, cubic meters, etc.) for this reduction activity will be identified in the "Units" box, immediately following the "Amount Recycled" data area.

\section{Amount Recycled:}

If you are not reporting a recycling activity then no action is required for these fields.

For a recycling activity enter the numeric value(s) for the quantity recycled on-site, offsite, or both. Do not double report values. Then click on the down-arrow of the units' box to select the correct units for the quantity report. Report only the quantity(s) recycled during this reporting period. 
Units:

Use the down-arrow in the units' box to bring up a list of units to select from. Highlight the correct units for the value(s) entered in the source reduction, on-site, and/or off-site field(s). Federal and State requirements are that sanitary and solid waste quantities be reported in kilograms; all other waste types are reported by volume. Conversions will be made to the required units for you.

Density:

If you reported sanitary or solid waste by volume or reported one of the other waste types by weight (mass), then you must provide a density factor for conversion. Otherwise you can omit these two fields. Enter a numeric value for the density. This may be a specific gravity ( $\mathrm{SpG}$ ), which is dimensionless, or a density having units of mass per unit volume, such as pounds per cubic foot. Next, click on the down-arrow in the "Density Units" box and select the appropriate units.

\section{Estimated Cost of Implementation:}

This field applies only to new activities that were implemented during the current reporting period.

Provide a dollar estimate of the total dollar cost to implement this waste reduction activity. Include equipment costs, charges for procedure modification and any expenses incurred during design, installation, and testing.

\section{Estimated Savings:}

Note - This field is for all activities regardless of the implementation date.

Enter the dollar amount of savings that were realized this reporting period through implementation of this waste reduction action. Do not include cost of implementation in the calculation. All the savings achieved from changes in disposal, packaging, handling, and administrative costs should be considered.

\section{Estimated Dollar Savings for Next 10 Years:}

Note - this is an essential reporting element.

Enter the dollar amount of savings that are anticipated over the next 10 years or the life of the activity if less than 10 years.

Do not include cost of implementation in the calculation. All the savings achieved from changes in disposal, packaging, handling, and administrative costs should be considered. 


\section{Status Report}

A help screen is available for each input element. Simply click on the button next to the input text.

Please supply the following information:

Facility Name:

Fiscal Year: $\square$

Quarter: ${ }^{\circ}$ 1st $\bigcirc$ 2nd ${ }^{\circ}$ 3rd ${ }^{\circ}$ 4th

Planned Budget

Actual Budget

Full Time Equivalents (FTEs)

Status on Secretarial Goals:
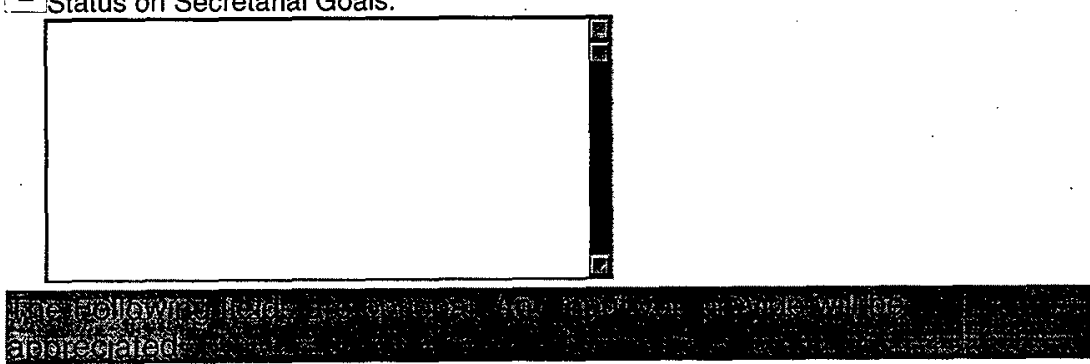

Status on Facility's Goals: 
Status on Waste Minimization Assessments Conducted:

Help

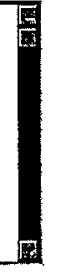

Planned opportunities identified through P2 in Design:

Planned opportunilies identified through P2 in De

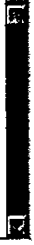

Comments:

国

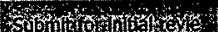

(t)

Note: Clicking the "Reset Values" box will clear (erase) all data you have entered in the current form.

\section{[ Top of Document] or [ Top of Form ]}

Retum to: Hanford Home Page or Pollution Prevention Home Page

For specific questions or comments see our Contacts List or send feedback to David Nichols

URL: http://apsq105.rl.gov/polprev/areport/status/addform.asp 


\section{D1.1.2 Guidance for Quarterly Status Report}

Help items for the Quarterly Status Report are provided below.

Facility Name:

Select the name of the Facility where the reduction/recycling/treatment occurred. If the facility does not appear in the list then leave blank. The facility name can be added by including it in the "Comments" field below.

\section{Planned Budget:}

Please provide the amount, in dollars, planned for WMin activities for reporting period.

\section{Actual Budget:}

Please provide the amount, in dollars, actually spent for WMin activities during reporting period.

\section{FTES:} period.

Please provide the number of FTEs involved in WMin activities during the reporting

\section{Secretarial Goal Status:}

For each of the wastes listed below provide 1) Baseline data or basis for the goal, 2) statement of the goal, and 3) status as of the end of the reporting period in achieving that goal.

- Routine low-level radioactive waste

- Routine low-level mixed waste

- Routine hazardous waste

- EPCRA 313 toxic chemicals releases and off-site transfers from routine operations (pertains to chlorine only)

- Sanitary waste from all activities

Example for a second quarter status report for FY 1999:

No LLW was generated by the facility in 1993 . However, 25 cubic meters of LLW waste was generated during the previous (FY 1998) fiscal year due to routine activities. A goal was established for FY 1999 to keep the generation of LLW at or below the amount generated during the previous FY. During the first quarter 12 cubic meters of LLW were generated and 2 cubic meters were generated during the second quarter. Operations are projecting that they will generate 12 cubic meters during the remainder of the fiscal year. The status report may contain: 
Routine LLW: 1) FY 1998 generated quantity ( 25 cubic meters) was the basis of the goal. 2) Goal was not to exceed the FY 1998 quantity. 3) A total of 14 cubic meters have been generated to date. It is anticipated that 1 cubic meter will exceed the goal.

\section{Facility Goal Status:}

This is an optional reporting element and does not include the status towards achieving the Secretary of Energy Goals

Please provide for each goal:

- A brief statement of the goal

- Current status in attaining that goal

WMAs:

This is an optional reporting element.

List the title of each WMA completed during this reporting period. Indicate if this assessment has been made available to all Hanford Site contractors by adding it to the WMA database.

Planned Opportunities Identified through P2 in Design:

If you have identified opportunities through $\mathrm{P} 2$ in design, provide a description and a projected implementation date.

Update these item in future quarterly reports only if the status changes.

\section{Comments:}

The comment field is used to document information that you wish to have included in your files. It will be maintained in the $\mathrm{P} 2$ database for you. However, the information is not reviewed by the P2/WMin Group nor used in any of the rollup reports prepared by the P2/WMin Group. 
DOE/RL-95-103, Rev. 3

This page intentionally left blank.

D-14 
DOE/RL-95-103, Rev. 3

APPENDIX E

WASTE MINIMIZATION CERTIFICATION FORM 
DOE/RL-95-103, Rev. 3

This page intentionally left blank. 
DOE/RL-95-103, Rev. 3

\section{WASTE MINIMIZATION CERTIFICATION FORM}

\section{CERTIFICATION:}

Facility or Contractor Name(s):

For the facility(ies) listed above, I certify that a waste minimization program is in place to reduce the volume and toxicity of hazardous waste that the facility(ies) generates to the degree determined to be economically practicable; and the proposed method of treatment, storage, and disposal is that practicable method currently available which minimizes the present and future threat to human health and the environment.

Manager:

(Printed name and signature)

Title:

Company:

Date:

This form should be signed and kept on file with generator pollution prevention documentation. 
DOE/RL-95-103, Rev. 3

This page intentionally left blank.

E-4 


\section{DISTRIBUTION}

\section{Number of Copies}

\section{ON-SITE}
A. V. Beard
S7-55
M. A. Barnard
$\mathrm{K} 8-50$
H. E. Bilson
R3-81
D. W. Bowser
A2-22
E. M. Bowers
S7-55
M. E. Burandt
$\mathrm{K} 8-50$
D. H. Chapin
R3-79
M. S. Collins
A5-18
G. Ellis-Balone
A5-15
C. A. Hansen
S7-41
M. R. Hahn
R3-79
R. S. Mercado
A2-45
J. H. Zeisloft
$\mathrm{H} 0-12$
Hanford Technical Library
P8-55
Public Reading Room
$\mathrm{H} 2-53$

B\&W Hanford Company

F. J. Carvo

N1-41

T. A. Dillhoff

N2-57

K. A. Hadley

R3-56

A. E. Hill

N2-57

B. B. Nelson-Maki

T5-54

J. R. Robertson

T5-54

D. E. Rasmussen

N1-47

M. M. Serkowski

L1-05

L. O. Waggoner

S0-19 
DOE/RL-95-103, Rev. 3

\section{Distribution (Continued)}

\section{Number of Copies}

\section{ON-SITE}

1

B\&W Protec, Inc.

M. B. Jaeger

G3-40

2

Bechtel Hanford Inc.

D. K. DuVon

$\mathrm{X} 1-86$

R. J. Landon

H0-18

1

DE\&S Hanford, Inc.

D. J. Watson

X3-79

4

Dyncorp Tri-Cities Services, Inc.

B. J. Dixon

G3-26

K. C. Hinkelman

G1-10

D. L. Klages

G3-26

C. E. Marple

NI-23

5

Fluor Daniel Hanford, Inc.

B. M. Akers

G5-54

R. L. Bisping

N1-26

C. G. Mattsson

N1-26

A. G. Miskho

H6-23

K. J. Svoboda

N1-26 
DOE/RL-95-103, Rev. 3

\section{Distribution (Continued)}

\section{Number of Copies}

$\underline{\text { ON-SITE }}$

2

Fluor Daniel Northwest, Inc.

R. A. Del Mar

E6-40

R. L. Newell

B7-41

1

Hanford Environmental Health Foundation

S. M. McInturff

H1-77

3

Lockheed Martin Hanford Corp.

J. S. Conrad

T4-08

K. A. Elsethagen

S5-03

P. C. Miller

R1-51

4

Lockheed Martin Services, Inc.

T. M. Holmes

G3-32

Document Processing Center (1)

A3-94

Central Files (1)

B1-07

Correspondence Control (1)

A3-01

$1 \quad$ Numatec Hanford Corp.

R. A. Kaldor

H5-25

$1 \quad$ Pacific Northwest National Laboratory

E. A. Raney

P7-79

Distribution-3 
DOE/RL-95-103, Rev. 3

\section{Distribution (Continued)}

Number of Copies

ON-SITE

Waste Management Federal Services of Hanford, Inc.

D. J. Alexander

S3-31

R. B. Barmettlor

L6-04

B. M. Barnes

T4-04

R. O. Bell

T3-04

H. C. Boynton

T4-52

J. B. Buckley, Jr.

T3-04

D. E. Clark

H6-06

D. L. Flyckt

S6-71

B. Griffin II

T6-30

C. R. Haas

T3-28

N. O. Hinojosa

$\mathrm{X} 3-67$

D. E. McKenney

H6-06

D. S. Merry

H6-06

D. H. Nichols

H6-06

S. L. Payton

S6-71

B. G. Place

H6-06

F. C. Schmidt

S6-30

M. M. Seay

S6-31

P. Segall

H6-06

Y. M. Shehadeh.

H6-06

R. W. Szelmeczka

L6-05

G. C. Triner

T3-05

O. J. Valero

H6-06

J. L. Westcott

T3-04

Waste Management Federal Services, Inc., Northwest Operations

S. E. Myers

$\mathrm{H} 1-12$ 